\title{
Improving Regional Socio-Economic Policies Based on Human Capital Management
}

\author{
GairatZuvaitovichUbaydullaev ${ }^{1}$ \\ ${ }^{1}$ Candidate of Economic Sciences, Associate Professor Department of "Information Technology Service" Karshi branch of \\ Tashkent University of Information Technologies named after Muhammad al- Khwarizm
}

\begin{abstract}
:
Theoretical substantiation and development of an organizational and economic mechanism for managing human capital in the development of the country. The purpose of the study is to study the theoretical and methodological foundations for the development of human capital and the digital economy in the economy of Uzbekistan. The purpose of this work is to identify the development of socio-economic relations that characterize the relationship of human capital as an innovative factor in socio-economic development. The study focuses on the concepts and strategies of the country's socio-economic development, developed by the state, giving priority attention to the growth of human capital and the development of the digital economy, the formation of targeted problem-solving programs.Comparisons and similarities in the work of our historical scientists in the development of the education system are the main goal in the growth of human capital.
\end{abstract}

Keywords:The national human capital, the education system, health, investment in human capital, the quality of education, the works of our historians and encyclopedias, the digital economy, the world economy, the socio-economic development of human capital. as innovative factors.

Article Received: 16th October, 2020; Article Revised: 30th December, 2020; Article Accepted: 08th January, 2021

\section{Introduction}

In his address to the Oliy Majlis on December 29, 2020, the President said:"We have set ourselves a big goal - to lay the foundations of the Third Renaissance in our country, to create an environment and conditions for training new Khorezmians, Beruni, Ibn. Sino, Mirzo Ulugbek, Navoi and Babur. At the same time, first of all, the development of education and upbringing, the choice of a healthy lifestyle, the development of science and innovation should be the main pillars of our national idea."'This inspired the people of Uzbekistan to new ideas. Because the creation of such a fund is based on scientific potential, enlightenment and education, the achievement of high quality human capital, the rule of law based on an innovative economy and an information society [1].Thus, the sphere of education and science was identified as one of the priorities of the strategy of actions for the socio-economic development of
Uzbekistan for 2017-2021. This, of course, is the concept of human capital and information, a close connection between information technologies,

moreover, information and communication technologies themselves arise at the intersection of information categories and human capital, since the flow of information covers all spheres of human life and plays an increasing role in the context of globalization of the world. community.During the period of modernization of the region's economy, the introduction of innovations and modern information technologies into the production process leads to the emergence of new knowledge-intensive sectors of the economy in the context of the independent development of human capital. The formation and development of innovative sectors of the modern economy leads to the formation of the characteristics of human capital as a factor in the emergence of these innovative new types of labor, that is, the development of the scale and quality of human capital is a broad concept. This requires initiative and the development of 
new ideas to improve the skills of human resources [2].

\section{Purpose of the study}

Improvement of regional socio-economic policy based on human capital management. Study of the theoretical and methodological foundations for the use of human capital and the development of the digital economy in the economy of Uzbekistan.To carry out radical structural reforms in the region's economy, it is necessary to pay special attention to the issues of technical re-equipment and modernization of industrial enterprises, the introduction of multidisciplinary technologies and the training of specialists capable of working for them. Development of scientific conclusions and practical recommendations in promising areas with the effective use of modern knowledge and digital economic technologies in the formation of an innovative economy.

\section{Scientific Essence}

The national human capital of Uzbekistan is an integral part of the country's national wealth, which includes socio-political capital, national intellectual priorities, national competitive advantages and the natural potential of the nation. The growth of national human capital is measured by its value.The development of national human capital is measured by its value, calculated in different ways - investments, that is, investments in education, science, enlightenment, health, physical and cultural activities, and so on. The features of national human capital are associated with the historical development of world civilizations and countries of the world, and are also gradually developing with the use of the socio-economic policy of developing countries.Modernization and diversification of production for the innovative development of the economy of Uzbekistan, the introduction of powerful technologies, the application of research results and know-how, as well as the use of recommendations of foreign scientific institutions and cooperation between the real sector of the economy. Increasing the efficiency of human capital in the development of an innovative economy in the country will mainly lead to an increase in the potential and quality of personnel, the introduction of modern technologies, economic efficiency and quality of life.

\section{About Research}

Although the formation of the theory of "human capital" dates back to the middle of the twentieth century, its roots go far back. Human capital is a set of knowledge and skills used to meet the various needs of an individual and society as a whole. The people of Uzbekistan are descendants of very powerful encyclopedic scientists.Looking into the past, our scientists saw human perfection, human happiness in the harmony of science, education, spirituality and enlightenment. This means that the genetics of the Uzbek people can become a solid foundation of human capital. In general, knowledge in the field of science, education, spirituality, education and economics has come down to us for thousands of years. The great scientists Imam Bukhariy, Imam Termeziy, Imam Moturidiy, AbdukhalikGijduvaniy,

BahovuddinNaqshbandiy and others in the creation of the first foundations of science, education and economic education in Central Asia. The contribution of such thinkers as Abu Ali ibn Sino, Abu RaikhanBeruniy, Musa al-Khorazmiy, Yusuf KhosKhojib, Amir Temur, MirzoUlugbek, AlisherNavoiy, ZakhiriddinBobur in the development of science, education and economic development is invaluable [3].

The first period of the Renaissance gave birth to famous geniuses recognized by the whole world in the 9th-12th centuries. In particular, world famous scientific and creative discoveries of dozens of great scientists, such as Muhammad al Khorazmiy, Ahmad Fargoniy, Abu RaikhanBeruniy, Abu Ali ibn Sino, 
Mahmud Zamakhshari, had an incomparable impact on the development of mankind.Scientific discoveries of scientists are of national and global importance, and scientifically based studies in their works are very important not only for that period, but also for the development of future generations and modern humanity. One of the remarkable qualities of our scientists is their knowledge in all areas, unequal knowledge of foreign languages, and we can confidently say that there were no thinkers who spoke no more than four or five languages.

The great scientist of the East Abu Nasr alFarobiy in his work on the analysis of the philosophy of Aristotle and in his book "The City of Noble People" paid great attention to science, education and economic needs, which is one of the main issues. According to his scientific conclusion, intelligent people are people who are virtuous, quick-witted, devoted to a useful cause, who know how to discover and invent innovations [3].

Abu Ali ibn Sino studies science and the acquisition of knowledge in relation to spirituality and enlightenment. $\mathrm{He}$ promotes the idea that science never gets old, travels the world and awakens people from ignorance and ignorance. In his "Laws of Medicine", he called people to enlightenment and economically and socially useful work [3].

Abu RayhonBeruniy understands that learning is pleasure and happiness. "My whole mind, my heart," he wrote, "is aimed at taking pleasure in gaining knowledge." "I consider it a great happiness," Encourages people to learn.

The work of Yusuf KhosKhojib "Kutadgubilig" also plays a special role in the development of economic thought in the East. The work focuses on such issues as proper wages, remuneration for work, its value, material wealth, education, occupation, strong social protection [3].

The second renaissance is associated with the name of Amir Temur. Indeed, the
Timurid period was the period of the Eastern Renaissance, which ensured the development of science, education, culture, spirituality and enlightenment. The development of science, culture, education, economic ideas of Amir Temur, his production and economic-political ideas, applied in practice, are of great importance. Amir Temur's work “Temur's Charter" summarizes the economic ideas of organization, stabilization, regulation of the economy, its sustainable growth [3].

The scientific heritage of Alisher Navoi is so rich and diverse that it embodies many valuable ideas in science, education, language learning, spirituality and enlightenment, as well as in economics. His scientific and economic views are described in the works "Mahbub-ul-kulub" and "Hamsa" [3].

The contribution of our great scientists and thinkers to education, labor productivity and economic growth in the past is reflected in the following concepts, in particular [3]:

- Thoughts about instilling knowledge, education and economic ideas in the Qur'an and hadith in the minds of people;

- Abu Nasr al-Farobiy and Abu Ali ibn Sina's views on knowledge and needs;

- Yusuf KhosKhojib's views on education, work and interests;

- Ideas of BahovuddinNaqshbandiy on the importance of education, socio-economic science and labor;

- Amir Temur's views on public administration, tax system, employment, investments in education and entrepreneurship, social protection and benefits set forth in the "Temur's Charter"; - Creative activity of MirzoUlugbek in science, measures for monetary reform and preferential tax system;

- AlisherNavoi's views on education, increasing the value of labor, trade, austerity, profit, property, youth education and other practical measures;

- Scientific views on economic development and creativity developed by 
Bobur, measures in the interests of the people based on tax policy and statehood. The contribution of our great scientists and thinkers who have lived for centuries in Central Asia to the formation of science, education and economy in the world community is of great importance.

\section{Research Methods}

The study used methods of systematic and scientific analysis of national values, science, education, comparison methods through descriptions of contemporaries and associates, methods of ensuring harmony of socio-economic, historical development, as well as analytical methods such as induction and deduction.

\section{Results}

Human capital (in the broadest sense) is a factor of intensive production in the development of society and the family, socio-economic development, including a qualified, knowledgeable part of the workforce, knowledge - intellectual and managerial means of labor, the environment and labor activity.

Human capital (in a short sense) is intelligence, health, knowledge, highquality and productive work, longevity and a good quality of life. The formation of an innovative economy in the region, the introduction of new technologies will undoubtedly depend on human capital, human capital spending will lead to the development of world civilizations and countries, increase labor productivity and production efficiency, and create productive employment.For the rapid innovative development of the modern economy in the country, great attention must be paid to the modernization and diversification of production, the introduction of high-performance technologies and the training of specialists capable of working in them. Based on this goal, the following tasks are being solved [4]:
- conducting a comprehensive study of forms and methods of increasing the competitiveness of personnel in the labor market;

- study the experience of developed countries in training and retraining in order to identify opportunities for the introduction of an innovative economy in Uzbekistan;

- Assessment of the modern education system;

- Determining the prospects for the development of training;

- Substantiation of the principles of improving the retraining and advanced training system;

- Development of measures to improve the management of the training system;

- Increased labor productivity leads to an increase in family income.

The basis of the new innovative economy is human capital, the main driving force behind the socio-economic development of modern society.Scientific research results are as follows [5]:

- develops a scientifically grounded interpretation of the quality of human capital, instead of investments in education, science, knowledge and in the process of obtaining production experience in foreign countries, demonstrates the competitiveness of both production and the labor market;

- Study the current state of the education system and evaluate the theoretical and methodological foundations for the use of human capital and the development of a modern economy in the transition to a new system using foreign experience;

- Defining the idea of the education system as a key regulator of methodological approaches to the formation of a skilled labor market, training, retraining and advanced training based on the needs of the labor market, taking into account changes in the form of teaching methods; 
- systematization of the main directions of modern foreign forms and teaching methods, taking into account the needs of the labor market of the Republic of Uzbekistan;

- development of scientific conclusions and practical recommendations in promising areas with the effective use of modern knowledge and digital economic technologies in the formation of an innovative economy based on retraining and advanced training, taking into account the increase in the competitiveness of the labor market;

-creation of new approaches to improving the quality of labor resources;

- effective use of the experience of countries with a developed information economy in the material components of the innovation system (technology transfer centers in IT services, technoparks, technopolises, innovation centers, clusters, development of high-tech areas, etc.);

- effective use of the experience of countries with a developed information economy in the material components of the innovation system (technology transfer centers in IT services, technoparks, technopolises, innovation centers, clusters, development of high-tech areas, etc.);

- development of principles for a new macroeconomic policy to meet the needs of the region's economy.

- the use of factor analysis methods using international indices and indicators to assess the effectiveness of national human capital in the country.

If you look at the analysis of the strategy of innovative development of the Republic of Uzbekistan for 2017-2021, legislation, decisions and decrees in the field of education adopted by the President in recent years, you can see that concrete measures are being taken to expand access to quality education:

- The Concept for the Development of the Higher Education System of the Republic of Uzbekistan until 2030 was approved [6];

- Over the past three years, 52 new higher educational institutions have been created in the country, bringing their number to 130 , of which 22 are higher educational institutions of prestigious foreign universities and their branches;

- In total, 2,701 foreign specialists from foreign countries are involved in the educational process of higher educational institutions;

- 1,797 faculty members were overseas for advanced training;

- Orientation of graduates of the magistracy to scientific activity with an increase in the number of graduates up to $40 \%$;

- The Concept for the development of the preschool education system until 2030 was approved and the Law of the Republic of Uzbekistan "On preschool education and upbringing" [7];

- New Law “On Education” adopted [8];

- The Concept for the development of the public education system until 2030 was approved [9];

- The Agency for the Development of the President, Creativity and Specialized Schools was established;

- The coverage of children from 3 to 7 years of age with preschool education increased to $85 \%$;

- 10 new Presidential schools and 3 creative schools were opened in the regions;

- 200 private secondary schools opened in 2020

- Non-state higher educational institutions have been created in the regions, that is, in cooperation with Korea in Fergana and Malaysia in Khorezm.

These indicators show that confidence in our future is, above all, the realization of 
great hopes for the future in the hearts of our children and their parents.

Under the leadership of the President, the state has invested heavily in the development of science, education, health care, spirituality and culture. The influx of scientifically grounded foreign experience and the use of their methods form a national education system that can withstand competition. The competitiveness of human resources is primarily determined by the ability to innovate and create new knowledge.

In his speeches dedicated to the 29th anniversary of our independence, the President noted that for the first time the period of a new Renaissance - the Third Renaissance - is being laid. Reflecting on the first steps taken in our country towards the Third Renaissance, first of all, I think, one should pay attention to the dynamics of its movement: On September 14, 2017, by the Decree of President Sh. Mirziyoyev, a specialized state boarding school named after Mirzo Ulugbek and a school named after Muhammad al-Khorezmi, specializing in advanced training in information and communication technologies, were created.

On November 29, 2017, the Ministry of Innovative Development was created by the Decree of the President. The Youth Academy was established under the Ministry of Innovative Development. Currently, the Agency for the Development of the President, Creativity and Special Schools, created under the Cabinet of Ministers, is operating. As a result, the agency system will allow the formation of completely new schools in the country, creating modern innovative methods of working with talented students [10].Work on presidential schools and creative schools continues. The selection and education of talents, the right direction in science will serve the development of human capital in our country.
This will lead to the education of worthy heirs of our great ancestors, the emergence of thinkers and brilliant scientists on this great land.

In order to systematically reform science, make full use of scientific and innovative potential, train highly qualified, independent personnel capable of competing in the labor market with modern knowledge, to modernize the scientific infrastructure to a new level, in accordance with the Presidential Decree, the Concept for the Development of Science until 2030 was approved [11].

For the purpose of digital transformation of the region, state and economic power in the regions, the widespread introduction of advanced technologies in the real sector of the economy, the implementation of new projects in the digital economy, the Strategy "Digital Uzbekistan - 2030" was approved [12].

To increase our children's interest in (IT) technologies and create conditions for their development into mature professionals, the Government will open 14 schools specializing in information technology in the regions in 2020, 82 in 2021, 64 in 2022 and 45 in 2023 [13] .

The development of information technology creates a material basis for the globalization of the economy. In 2015, Uzbekistan took 122nd place out of more than 140 countries in the ranking of the International Global Innovation Index, and in 2020 Uzbekistan took 93rd place out of more than 131 countries [13]. Under the leadership of the heads of our government, urgent programs are being implemented that reflect the position of the Republic of Uzbekistan in the Global Competitiveness Index of the World Economic Forum, that is, with the participation of government agencies responsible for improving the country's position in international rankings and individual indicators.

Globalization means, first of all, the incomparable acceleration of the existing 
socio-economic life. achievements. Thanks to the development and application of information technology, many conveniences appear in our daily life. With the development of digital technologies, a person can save a lot of money and time by using the services they need faster by buying the products they need cheaply over the Internet. Of course, the development of information and communication technologies, the introduction of modern technologies into our life creates many positive opportunities in the life of every person.

The Resolution of the President of the Republic of Uzbekistan dated April 28, 2020 "On measures for the widespread introduction of the digital economy and electronic government" sets the task by 2023 to double the share of the digital economy in GDP and triple the volume of services in this area [14]. At present, the share of information technology in the gross domestic product (GDP) of Uzbekistan is $2.4 \%$.In the future, it is planned to increase the share of information and communication technology services in the national GDP to $5 \%$ in 2025 and to $10 \%$ in 2030 . Research by World Bank experts shows that an increase in the number of high-speed Internet users by $10 \%$ will allow the national economy to increase GDP by 0.5 $1.5 \%$ annually. The global digital economy is already growing at nearly 20 percent per year.In particular, the United States is expected to generate an additional \$20 trillion by 2025 from digitizing the industry. In South Korea, the introduction of "e-government" and "e-mediation" brings in 10-15 billion dollars a year. This is $30-40$ times more than the cost of the digital economy [15].

Benefits in the development of the digital economy: production;
-Increasing labor productivity in ,
-Increasing the competitiveness of entrepreneurs;

-Reduction of production costs;

-Creation of new jobs; professions;

- The emergence of new modern

- overcoming poverty and eliminating social inequality;

-development of science;

These are just a few of the benefits of the digital economy. The development of the digital economy has a positive effect on our daily life, provides many additional options for the average user and while ensuring the growth and development of the market. The IT services market has created a demand for professionals with deep knowledge of their specialty, the ability to speak foreign languages, as well as remote collaboration, creative thinking, professional responsibility and flexibility. The President urged young people to increase their interest in culture and art, create the necessary conditions for them to demonstrate their abilities in sports, organize the effective use of computer technologies and the Internet, especially among young people, to raise the morale of young people. The widespread dissemination of reading among women, the five important initiatives to create employment for women launched in 2019, are also in fact one of the most daring steps towards serious reform of the country and society, and all of them will contribute to the increase of national human capital.

\section{Conclusion}

In conclusion, today the society of Uzbekistan has become a country capable of great changes and reforms. Thanks to the large-scale reforms carried out in the education system of our country, unique opportunities have been created for the younger generation to acquire modern knowledge and acquire a profession. Within the framework of such noble efforts aimed at educating the sons and 
daughters of our country as harmoniously developed people, special attention is paid to educating young people deeply and based on innovative technologies. The most important thing is that our young people come to the fore as initiators of such reforms. The foundation of the social and spiritual activity of our youth is the embodiment of the Third Renaissance. The New Renaissance will serve to create great wealth in our country through a combination of science, education, spiritual and educational knowledge and ideological values, will increase the national human capital, improve the lives of our people and leave a legacy to future generations.

Of course, globalization is an irreversible process that is taking place all over the world. The main attention is paid to the history of globalization, achieved by human society in the process of globalization, the present, achievements and shortcomings, philosophical conclusions made on a long historical path. In this regard, our history testifies to the fact that scientists who grew up in our country in the field of science, religion and art are known all over the world. While Abu Nasr Farobi made a significant contribution to the development of world philosophy, our scientists, such as Abu Raikhan Beruni, Abu Ali ibn Sino, Zamakhshari, Khorezmi, Mirzo Ulugbek, raised world science to new heights. Such great scientists as Imam Bukhara, Imam Termezi, Imam Moturidi, Abdukhalik Gijduvani, Bahovuddin Naqshbandi, Burkhaniddin Marginoni, Abul Muin Nasafi, are shining stars of pride of the entire Muslim world and the revival of the nation's ideological values. The greatness of state administration and military art of Amir Temur and Mirzo Babur is recognized throughout the world.

Economists estimate that when aggregating individual investment in human capital, the difference between investment in human capital and per capita income in different countries ranges from 10 to 30 percent.

\section{References}

[1] Message from the President of the Republic of Uzbekistan Shavkat Mirziyoyev to the Oliy Majlis dated January 24, 2020. Folk speech, January 25, 2020.

[2] Decree of the President of the Republic of Uzbekistan No. PF5953 of March 2, 2020 "On the State Program for the Implementation of the Action Strategy in Five Priority Areas of Development of the Republic of Uzbekistan for 2017-2021 in the Year of Science, Education and the Digital Economy".

[3] G.Z. Ubaydullaev "Methodology of economic education" textbook. Tashkent - "Science and Technology" - 2020.

[4] G.Z. Ubaydullaev "Completion of training and retraining of personnel is a vital condition for the existence of the labor market." Scientific and Educational Association of the Intelligentsia of Uzbekistan. Tashkent-1997 -p-31

[5] G.Z. Ubaydullaev "The future is unthinkable without education." Economics and Statistics. Socioeconomic journal-T.1998 -p. 4.

[6] Decree of the President of the Republic of Uzbekistan NoPD5847 dated October 8, 2019 on the approval of the "Concept for the development of the higher education system in the Republic of Uzbekistan until 2030".

[7] Law of the Republic of Uzbekistan 12, Law of the Republic of Uzbekistan "On preschool education and upbringing",ORQ595 16.12.2019

[8] Law of the Republic of Uzbekistan "On Education" No ZRU-637. 09/23/2020 
[9] Decree of the President of the Republic of Uzbekistan No PD5712 dated April 29, 2019 "On approval of the Concept for the development of the public education system until 2030".

[10] Mavrulov. "The Third Renaissance is the basis for a worthy future." New Uzbekistan newspaper, October 6, 2020, issue 190.

[11] Decree of the President of the Republic of Uzbekistan No. PD6097 dated October 29, 2020 "On approval of the Concept for the development of science until 2030".

[12] Decree of the President of the Republic of Uzbekistan No. PF6079 dated October 5, 2020 “On approval of the Strategy" Digital Uzbekistan - 2030.

[13] Speech by the President of the Republic of Uzbekistan ShavkatMirziyoyev "Teachers and trainers are a great strength, support and backbone in building a new Uzbekistan." October 1, 2020, No. 188.

[14] N. Dzhumaev"Without the digital economy, the country's economy has no future." New Uzbekistan newspaper, September 30, 2020, issue 187.

[15] AbdurakhmanovK.Kh. "Analysis of modern innovative approaches to human development management." Scientific and analytical journal "Science and Practice" of the Russian Economic University named after G. V. Plexanov: T. 10, No. 29, 2018. 